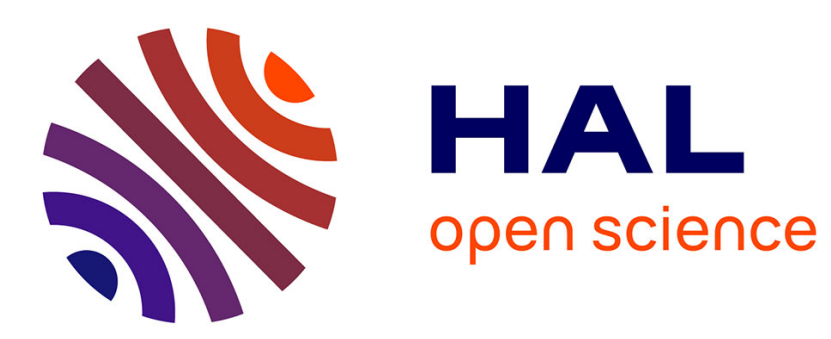

\title{
Analysis of the 2015 American and European guidelines for the management of infective endocarditis
}

\author{
Pierre Tattevin, Jean-Luc Mainardi
}

\section{To cite this version:}

Pierre Tattevin, Jean-Luc Mainardi. Analysis of the 2015 American and European guidelines for the management of infective endocarditis. Médecine et Maladies Infectieuses, 2016, 46 (8), pp.406-410. 10.1016/j.medmal.2016.05.008 . hal-01494110

HAL Id: hal-01494110

\section{https://hal-univ-rennes1.archives-ouvertes.fr/hal-01494110}

Submitted on 11 Apr 2017

HAL is a multi-disciplinary open access archive for the deposit and dissemination of scientific research documents, whether they are published or not. The documents may come from teaching and research institutions in France or abroad, or from public or private research centers.
L'archive ouverte pluridisciplinaire HAL, est destinée au dépôt et à la diffusion de documents scientifiques de niveau recherche, publiés ou non, émanant des établissements d'enseignement et de recherche français ou étrangers, des laboratoires publics ou privés. 


\section{Analyse des recommandations américaines et européennes de 2015 pour la prise en charge des endocardites infectieuses}

\section{Analysis of the 2015 American and European guidelines for the management of infective endocarditis}

\section{Pierre Tattevin' ${ }^{1}$ Jean-Luc Mainardi ${ }^{2}$}

1 Maladies Infectieuses et Réanimation Médicale, CHU Pontchaillou, Rennes

2 Unité Mobile de Microbiologie Clinique, Service de Microbiologie, Hôpital Européen Georges Pompidou, Université Paris Descartes, Paris

* Corresponding author: Pierre Tattevin

Service des Maladies Infectieuses et Réanimation Médicale, CHU Pontchaillou, 35033

Rennes cedex, France.

Email: pierre.tattevin@chu-rennes.fr

Mots clés: endocardite infectieuse ; recommandations; Staphylococcus aureus; Streptococcus sp. ; tomographie par émission de positons

Keywords: infective endocarditis; guidelines; Staphylococcus aureus; Streptococcus sp.; positron emission tomography 


\section{Résumé}

La prise en charge optimale des endocardites infectieuses nécessite le recours à des expertises multiples (infectiologues, cardiologues, microbiologistes, chirurgiens cardiaques, réanimateurs). En l'absence de haut niveau de preuves pour la plupart des étapes de cette prise en charge, les recommandations internationales ont toujours été particulièrement attendues dans ce domaine, et dans l'ensemble plutôt bien respectées. L'analyse rigoureuse des données de la littérature, et les expertises qui composent les groupes multidisciplinaires chargés de ces recommandations, font en général autorité.

Dans ce contexte, la publication à quelques semaines d'écart, en 2015, des révisions des recommandations américaines et européennes, a semé le trouble. On y retrouve des discordances nettes sur des propositions thérapeutiques importantes comme le traitement empirique (pénicilline $M+$ pénicilline $A+$ gentamicine pour les européens dans les endocardites aiguës sévères ; pénicilline $A+$ inhibiteur de bêta-lactamases + gentamicine pour les américains), ou le traitement de première intention des endocardites à Staphylococcus aureus, principal pathogène responsable d'endocardites en 2016 (triméthoprime-sulfaméthoxazole + clindamycine en alternative dans les recommandations européennes, tandis que ce régime n'est pas même mentionné dans les recommandations américaines). D’autres différences sont observées, moins radicales: la place de la tomographie par émission de positons marquée au ${ }^{18} \mathrm{~F}$ fluorodésoxyglucose et les modalités d'administration des aminosides.

Nous détaillerons les principaux changements apportés par ces recommandations, leurs désaccords et les arguments pour et contre qui peuvent vous aider à sélectionner le meilleur traitement pour vos patients. 


\section{Abstract}

The optimal management of infective endocarditis requires a broad range of expertise (infectious disease specialists, cardiologists, microbiologists, cardiac surgeons, and intensivists). Given the low level of evidence currently available to support the management of infective endocarditis, international guidelines have always been particularly awaited and rather well implemented. Their cautious analysis of the medical literature and the range of expertise combined within the groups in charge of these guidelines are usually broadly acknowledged and respected.

The publications, a few weeks apart, of the 2015 updates of the American and European guidelines, was quite disturbing. Indeed, several discrepancies on major therapeutic propositions were observed, including empirical treatment (penicillin $\mathrm{M}+$ penicillin $\mathrm{A}+$ gentamicin for Europeans in acutely ill patients; penicillin A + beta-lactamase inhibitor + gentamicin for Americans), or first-line treatment for the most common pathogen responsible for endocarditis in 2016, Staphylococcus aureus (trimethoprimsulfamethoxazole + clindamycin as an alternative in European guidelines, while this regimen is not even mentioned in the American guidelines). Other discrepancies were observed, although less significant: the role of positron emission tomography labelled with ${ }^{18}$ F-fluorodeoxyglucose and administration modalities for aminoglycosides.

We aimed to detail the main changes brought upon by these guidelines, their discrepancies, and the 'pros' and 'cons' that may help you select the best treatment regimen for your patients. 
The simultaneous publication of the American [1] and European [2] guidelines on infective endocarditis highlights, for the first time, the arbitrary choices made to compile these recommendations. Although based on the same literature analysis and drafted by experts used to share knowledge, the American and European guidelines do not put forward the same treatment suggestions. Discrepancies could already be observed in previous versions but they were less significant than the ones observed in the 2015 guidelines, and could partly be justified by the development of scientific knowledge that took place in-between the publication dates (American guidelines: 2005; European guidelines: 2009). This kind of argument cannot be advanced with the 2015 updates as both guidelines were drafted and published at the same time.

\section{A) American guidelines [1]}

The new recommendations:

- take into consideration the growing complexity and diversity of these diseases, and advocate for a multidisciplinary and individual management of patients presenting with a suspicion of endocarditis;

- highlight that this complexity has led experts to no longer recommend a "universal" empirical antibiotic therapy for endocarditis. The American updates rather suggest to consider characteristics on a case-by-case basis and suggest using a specific table (Epidemiological factors influencing the etiological diagnosis of infective endocarditis). The main causes for each specific situation are summarized in this table, which must be used for empirical antibiotic therapy decision when indicated;

- stress that the need for an urgent initiation of antibiotic therapy in case of an endocarditis suspicion remains rare and that the most common mistake lies in excessive prescriptions that lead to problematic situations of undocumented endocarditis.

Antibiotic therapies recommended in the 2015 updates come as no surprise. The main modifications suggested were already implemented by many physicians given the publication date of the previous guidelines. The authors of the latter guidelines admitted that they ought to be updated on a more regular basis in light of the evolution of resistance profiles and scientific progress. We aimed to highlight the main discrepancies 
between the 2015 and 2005 American guidelines. As we did not always agree on the recommendations, we decided to discuss them on the basis of pros and cons arguments.

\section{1) Antibiotic therapy}

\section{a) S. aureus endocarditis and aminoglycosides}

The 2015 American and European updates no longer suggest using aminoglycosides in the treatment of native valve staphylococcal endocarditis, regardless of the sensitive or resistant nature of the strain to methicillin. American and European guidelines both recommend to keep using gentamicin during the first two weeks of treatment for prosthetic valve staphylococcal endocarditis: two or three injections/day for Americans, and one or two injections/day for Europeans.

Pierre Tattevin (Pro). It was time to make official what was already implemented by many experts: the efficacy of aminoglycosides has never been proven in staphylococcal endocarditis, even when evaluated in a randomized study [3]. Conversely, recent data demonstrated their deleterious effect, even when administered for a few days [4].

Jean-Luc Mainardi (Con). Suggesting to no longer use aminoglycosides in the treatment of staphylococcal endocarditis is based on the lack of evidence supporting the benefit of the two-drug combination therapy versus monotherapy on mortality [5]. However, adding gentamicin to a beta-lactam or a glycopeptide regimen is associated with a good in vitro synergy rapidly leading to bactericidal activity [6], especially as glycopeptides alone have a slow bactericidal activity [7]. The results of studies based on animal models, conducted as early as 1975 by Sande \& Johnson, also demonstrated that an aminoglycoside + beta-lactam combination therapy was associated with a more rapid bacterial eradication from blood cultures and vegetations compared with a beta-lactam regimen alone [6].

Considering these arguments, many facilities involved in the management of patients presenting with native valve staphylococcal endocarditis are expected to keep on using the beta-lactam or glycopeptide + gentamicin combination during the initial phase ( 3 to 5 days) as the benefit of this regimen has been demonstrated during this phase in the animal model. Conversely, it should be noted that aminoglycosides are still being recommended for the first 14 days of prosthetic valve endocarditis treatment, while there is no major evidence supporting such regimen. In my opinion, administering 
aminoglycosides twice daily (instead of three times a day due to an increased risk of toxicity) seems to be adequate to obtain a synergistic effect.

\section{b) Streptococcal endocarditis and aminoglycosides}

Gentamicin must be administered with a single daily dose of $3 \mathrm{mg} / \mathrm{kg}$ for streptococcal endocarditis.

Pierre Tattevin (Pro). This is once again a retrospective validation of an already widely implemented (especially in France [8]), evidence-based practice (better tolerability and effectiveness of aminoglycosides with a single daily administration).

Jean-Luc Mainardi (Con). Aminoglycosides do not have any inherent activity against Streptococcus species due to their naturally low level of resistance, with a minimum inhibitory concentration (MIC) ranging from 0.5 to $2 \mathrm{mg} / \mathrm{L}$. Aminoglycosides are not used to obtain an optimal peak concentration, but rather to obtain a synergy with a betalactam or a glycopeptide. As aminoglycosides have a biological half-life of approximately two hours, the once daily administration does not allow patients with a normal renal function to maintain a sustained blood concentration of gentamicin over 24 hours as well as a sustained synergy over a 24-hour period. Therefore, administering aminoglycosides twice daily seems to make more sense to obtain a sustained synergy over 24 hours.

\section{c) Daptomycin and methicillin-resistant staphylococcal endocarditis}

The European and American guidelines suggest using daptomycin as a first-line alternative in the treatment of methicillin-resistant staphylococcal endocarditis. They advocate for a higher dose than the one recommended in the product marketing authorization: $10 \mathrm{mg} / \mathrm{kg} /$ day in Europe and $\geq 8 \mathrm{mg} / \mathrm{kg} /$ day in the United-States.

Jean-Luc Mainardi, Pierre Tattevin (con). Although cohort studies demonstrated the good outcome associated with the use of daptomycin in the treatment of left-sided endocarditis $[9,10]$, it should be reminded that it has only been approved in the treatment of right-sided endocarditis where it only demonstrated a non-inferiority versus conventional treatments [11].

\section{d) Enterococcal endocarditis}


Enterococcal endocarditis may either be treated with a combination of penicillin (A or G) and gentamicin (2-3 injections/day, $3 \mathrm{mg} / \mathrm{kg}$ ) for four to six weeks, or with a combination of penicillin A (12 g/day) and ceftriaxone (2 $\mathrm{g}$ twice daily) for six weeks.

Pierre Tattevin, Jean-Luc Mainardi (Pro). We expected this combination of two betalactam antibiotics to be recommended as a first-line alternative in light of the Spanish publications following studies showing evidence of an in vitro synergy between amoxicillin and third-generation cephalosporins (cefotaxime, ceftriaxone) by inhibition synergy on targets [12]. However, we cannot help but notice that the American guidelines did not take into consideration Scandinavian publications that strongly suggested discontinuing aminoglycosides after two weeks of treatment when favoring the penicillin-gentamicin combination for enterococcal endocarditis. The European guidelines are rather more innovative on that matter [2].

\section{2) Imaging techniques}

Apart from antibiotic therapy, the American guidelines did not stress the importance of ${ }^{18} \mathrm{~F}$-fluorodeoxyglucose (FDG) positron emission tomography (PET) as much as the European ones [2]. Indeed, the latter decided to define FDG PET as a major Duke criterion in the presence of hyperactivity near a prosthetic valve implanted $>3$ months earlier.

\section{Pierre Tattevin, Jean-Luc Mainardi (Con)}

The cautious approach adopted by the American guidelines may be justified by the still limited data available on the diagnostic benefit of FDG PET. However, ongoing studies (e.g., national hospital programs for clinical research: ENDOPET and TEPvENDO in France) should provide robust data on the use of this technique. It should also be noted that Duke criteria were approved on the basis of thorough studies evaluating their efficacy in various populations. New imaging techniques have yet to be validated by this kind of studies. Defining the PET results as "major Duke criteria" for the diagnosis of prosthetic valve endocarditis is quite premature.

\section{3) Anticoagulation}

The American guidelines sometimes promote a more audacious approach than the European ones, especially when suggesting to "discontinue all anticoagulation in patients with $S$. aureus prosthetic valve IE who have experienced a recent central 
nervous system embolic event for at least the first two weeks of antibiotic therapy" (all the while admitting to the low level of evidence - C - supporting this recommendation [1]).

\section{Jean-Luc Mainardi and Pierre Tattevin do not agree with this item.}

\section{B) Particularities of the European guidelines}

\section{a) Trimethoprim-sulfamethoxazole + clindamycin combination therapy}

The main particularity of the European guidelines lies in their promoting as an alternative, and regardless of intolerance, allergy, or resistance, the high dose combination of trimethoprim-sulfamethoxazole $(960 \mathrm{mg} /$ day of trimethoprim, $4,800 \mathrm{mg} /$ day of sulfamethoxazole) for six weeks with clindamycin (1,800 mg/day) for one week in the treatment of native valve $S$. aureus endocarditis.

Pierre Tattevin, Jean-Luc Mainardi (con). This combination is not mentioned in the American guidelines, but Europeans justify its use by the positive opinion of some experts and put forward the results of a single center observational study of 31 patients [13]. However, the authors of two larger randomized studies strongly suggest that co-trimoxazole is not as effective as vancomycin in the treatment of S. aureus bacteremia $[14,15]$, and that treating endocarditis with clindamycin could be associated with an increased risk of early relapse due to resistance selection [16]. Moreover, the potential hematotoxicity of trimethoprim-sulfamethoxazole during six weeks when administered at such high doses (similar dosing as the one recommended in the curative treatment of pneumocystis but over a treatment period twice as long) is mentioned neither in the original publication of the regimen [13] nor in the guidelines [2]. However, this hematotoxicity is quite significant if we take into consideration the tolerability profile of the combination therapy.

\section{b) Empirical treatment of endocarditis}

The other major discrepancy between the European and American guidelines lies in the empirical treatment of severe presentations of acute community-acquired endocarditis. The 2015 European updates recommend the use of penicillin A (ampicillin, $12 \mathrm{~g} /$ day) + penicillin M (cloxacillin or oxacillin, $12 \mathrm{~g} /$ day) + gentamicin (3 mg/kg/day) [2], while 
the 2009 guidelines recommended combining amoxicillin-clavulanic acid or ampicillinsulbactam (12 g/day) with gentamicin (3 mg/kg/day) [17].

Pierre Tattevin (con). The modification is based on a single evidence: the results of a retrospective cohort study suggesting that treating multidrug-susceptible $S$. aureus bacteremia with antistaphylococcal beta-lactams (cloxacillin or cefazolin; $n=131$ ) would be associated with a better survival versus treatment with a combination of beta-lactam + beta-lactamase inhibitor $(n=98)$ [18]. The benefit of a combination with two high dose penicillins has barely been studied, but several French centers have reported an increase in acute renal failure caused by high dose beta-lactams over the past few years in elderly patients presenting with comorbidities. Most patients presenting with endocarditis in 2016 correspond to this profile. Similar to the new treatment regimen with co-trimoxazole at high doses and clindamycin, we should mention the discrepancies between the factors that brought upon the updates (hypotheses supported by a low level of evidence) and the risks associated with the suggested alternatives (understudied risks with potential major consequences).

Jean-Luc Mainardi (Pro). Acute severe endocarditis is often caused by S. aureus. This three-drug combination therapy including a penicillin M has the advantage of covering $S$. aureus and getting rid of the problem related to the potentially insufficient diffusion of beta-lactamase inhibitors (clavulanic acid) in vegetations. It is thus quite useful to stress that more than $90 \%$ of $S$. aureus strains produce a penicillinase. The tolerability of a treatment regimen with two beta-lactams is a real issue, but it is useful to remind that: $i$ ) the empirical treatment of acute endocarditis is usually of short duration as diagnosis is established within 48 hours in more than 95\% of cases; and that ii) Spanish studies of enterococcal endocarditis did not report any increase in the risk of renal failure with the combination regimen of ampicillin (12 g) and ceftriaxone (4 g) when administered for six weeks $[19,20]$.

Although the 2015 European and American updates both insist on the importance of a multidisciplinary and individual approach by an "endocarditis team" consisting of cardiologists, cardiac surgeons, infectious disease specialists, microbiologists, and anesthesiologists, the predominance of cardiac specialties among the authors of the 2015 European guidelines must be pointed out. Noteworthy, unlike the 2009 updates 
and the 2015 American guidelines, the 2015 European updates have not been approved by any infectious disease society before being published.

\section{Conflicts of interest}

The authors report no conflict of interest.

\section{Contributions}

PT and JLM equally contributed to writing the article after vigorous but always friendly debates. 


\section{Références}

1. Baddour LM, Wilson WR, Bayer AS, et al. Infective Endocarditis in Adults: Diagnosis, Antimicrobial Therapy, and Management of Complications: A Scientific Statement for Healthcare Professionals From the American Heart Association. Circulation 2015; 132(15): 1435-86.

2. Habib G, Lancellotti P, Antunes MJ, et al. 2015 ESC Guidelines for the management of infective endocarditis: The Task Force for the Management of Infective Endocarditis of the European Society of Cardiology (ESC)Endorsed by: European Association for Cardio-Thoracic Surgery (EACTS), the European Association of Nuclear Medicine (EANM). European heart journal 2015.

3. Ribera E, Gomez-Jimenez J, Cortes E, et al. Effectiveness of cloxacillin with and without gentamicin in short-term therapy for right-sided Staphylococcus aureus endocarditis. A randomized, controlled trial. Ann Intern Med 1996; 125(12): 969-74.

4. Cosgrove SE, Vigliani GA, Fowler VG, Jr., et al. Initial low-dose gentamicin for Staphylococcus aureus bacteremia and endocarditis is nephrotoxic. Clinical infectious diseases : an official publication of the Infectious Diseases Society of America 2009; 48(6): 713-21.

5. Watanakunakorn C, Baird IM. Prognostic factors in Staphylococcus aureus endocarditis and results of therapy with a penicillin and gentamicin. Am J Med Sci 1977; 273(2): 133-9.

6. Sande MA, Johnson ML. Antimicrobial therapy of experimental endocarditis caused by Staphylococcus aureus. J Infect Dis 1975; 131(4): 367-75.

7. Grohs P, Kitzis MD, Gutmann L. In vitro bactericidal activities of linezolid in combination with vancomycin, gentamicin, ciprofloxacin, fusidic acid, and rifampin against Staphylococcus aureus. Antimicrobial agents and chemotherapy 2003; 47(1): 418-20.

8. Beraud G, Le Moal G, Elsendoorn A, et al. A survey on the use of gentamicin in infective endocarditis. European journal of clinical microbiology \& infectious diseases : official publication of the European Society of Clinical Microbiology 2012; 31(7): 1413-8.

9. Carugati M, Bayer AS, Miro JM, et al. High-dose daptomycin therapy for left-sided infective endocarditis: a prospective study from the international collaboration on endocarditis. Antimicrobial agents and chemotherapy 2013; 57(12): 6213-22.

10. Kullar R, Casapao AM, Davis SL, et al. A multicentre evaluation of the effectiveness and safety of high-dose daptomycin for the treatment of infective endocarditis. J Antimicrob Chemother 2013; 68(12): 2921-6.

11. Fowler VG, Jr., Boucher HW, Corey GR, et al. Daptomycin versus standard therapy for bacteremia and endocarditis caused by Staphylococcus aureus. N Engl J Med 2006; 355(7): 653-65.

12. Mainardi JL, Gutmann L, Acar JF, Goldstein FW. Synergistic effect of amoxicillin and cefotaxime against Enterococcus faecalis. Antimicrobial agents and chemotherapy 1995; 39(9): 1984-7.

13. Casalta JP, Zaratzian C, Hubert S, et al. Treatment of Staphylococcus aureus endocarditis with high doses of trimethoprim/sulfamethoxazole and clindamycin-Preliminary report. International journal of antimicrobial agents 2013; 42(2): 190-1. 
14. Markowitz N, Quinn EL, Saravolatz LD. Trimethoprim-sulfamethoxazole compared with vancomycin for the treatment of Staphylococcus aureus infection. Annals of internal medicine 1992; 117(5): 390-8.

15. Paul M, Bishara J, Yahav D, et al. Trimethoprim-sulfamethoxazole versus vancomycin for severe infections caused by meticillin resistant Staphylococcus aureus: randomised controlled trial. BMJ (Clinical research ed) 2015; 350: h2219.

16. Watanakunakorn C. Clindamycin therapy of Staphylococcus aureus endocarditis. Clinical relapse and development of resistance to clindamycin, lincomycin and erythromycin. The American journal of medicine 1976; 60(3): 419-25.

17. Habib G, Hoen B, Tornos $P$, et al. Guidelines on the prevention, diagnosis, and treatment of infective endocarditis (new version 2009): the Task Force on the Prevention, Diagnosis, and Treatment of Infective Endocarditis of the European Society of Cardiology (ESC). Endorsed by the European Society of Clinical Microbiology and Infectious Diseases (ESCMID) and the International Society of Chemotherapy (ISC) for Infection and Cancer. European heart journal 2009; 30(19): 2369-413.

18. Paul M, Zemer-Wassercug N, Talker 0 , et al. Are all beta-lactams similarly effective in the treatment of methicillin-sensitive Staphylococcus aureus bacteraemia? Clinical microbiology and infection : the official publication of the European Society of Clinical Microbiology and Infectious Diseases 2011; 17(10): 1581-6.

19. Fernandez-Hidalgo N, Almirante B, Gavalda J, et al. Ampicillin plus ceftriaxone is as effective as ampicillin plus gentamicin for treating enterococcus faecalis infective endocarditis. Clinical infectious diseases : an official publication of the Infectious Diseases Society of America 2013; 56(9): 1261-8.

20. Pericas JM, Cervera C, del Rio A, et al. Changes in the treatment of Enterococcus faecalis infective endocarditis in Spain in the last 15 years: from ampicillin plus gentamicin to ampicillin plus ceftriaxone. Clinical microbiology and infection : the official publication of the European Society of Clinical Microbiology and Infectious Diseases 2014; 20(12): 01075-83. 
Tableau 1. Principales antibiothérapies de première ligne dans les recommandations européennes et américaines 2015 de prise en charge des endocardites infectieuses

Table 1. Main first-line antibiotic therapies included in the 2015 European and American guidelines for the management of infective endocarditis

\begin{tabular}{|c|c|c|}
\hline & 2015 American guidelines & 2015 European guidelines \\
\hline $\begin{array}{l}\text { Empirical } \\
\text { antibiotic } \\
\text { therapies }\end{array}$ & $\begin{array}{l}\text { Depends on symptom evolution } \\
\text { and epidemiological factors }\end{array}$ & $\begin{array}{l}\text { Community-acquired (severe } \\
\text { presentation): }{ }^{*} \text { ampicillin }+ \\
\text { (cl)oxacillin + gentamicin } \\
\text { Nosocomial: } \\
\text { vancomycin }+ \text { gentamicin }+ \\
\text { rifampicin } * *\end{array}$ \\
\hline $\begin{array}{l}\text { Native valve } \\
\text { staphylococcal } \\
\text { endocarditis }\end{array}$ & $\begin{array}{l}\text { Methicillin-susceptible: } \\
\text { (cl)oxacillin } \\
\text { Methicillin-resistant: } \\
\text { vancomycin or daptomycin }\end{array}$ & $\begin{array}{l}\text { Methicillin-susceptible: } \\
\text { (cl)oxacillin } \\
\text { Methicillin-resistant: } \\
\text { vancomycin or daptomycin } \\
\text { Alternative (in both of the above } \\
\text { situations): } \\
\text { trimethoprim-sulfamethoxazole } \\
\text { + clindamycin }\end{array}$ \\
\hline $\begin{array}{l}\text { Prosthetic valve } \\
\text { staphylococcal } \\
\text { endocarditis }\end{array}$ & $\begin{array}{l}\text { Methicillin-susceptible: } \\
\text { (cl)oxacillin + gentamicin ( } 2 \text { or } \\
3 \text { uptakes/day) + rifampicin } \\
\text { Methicillin-resistant: } \\
\text { vancomycin + gentamicin ( } 2 \text { or } \\
3 \text { uptakes/day) + rifampicin }\end{array}$ & $\begin{array}{l}\text { Methicillin-susceptible: } \\
\text { (cl)oxacillin + gentamicin (1 or } 2 \\
\text { uptakes/day) + rifampicin } \\
\text { Methicillin-resistant: } \\
\text { vancomycin + gentamicin (1 or } \\
2 \text { uptakes/day) + rifampicin }\end{array}$ \\
\hline $\begin{array}{l}\text { Susceptible } \\
\text { streptococcal } \\
\text { endocarditis }\end{array}$ & $\begin{array}{l}\text { "Two-week regimen": } \\
\text { penicillin G or ceftriaxone + } \\
\text { gentamicin (single daily dose) } \\
\text { "Four-week regimen": } \\
\text { penicillin G or ceftriaxone }\end{array}$ & $\begin{array}{l}\text { "Two-week regimen": } \\
\text { penicillin G or amoxicillin or } \\
\text { ceftriaxone + gentamicin (single } \\
\text { daily dose) } \\
\text { "Four-week regimen": } \\
\text { penicillin G or amoxicillin or } \\
\text { ceftriaxone }\end{array}$ \\
\hline $\begin{array}{l}\text { Susceptible } \\
\text { enterococcal } \\
\text { endocarditis }\end{array}$ & $\begin{array}{l}\text { Regimen "A": } \\
\text { penicillin G or ampicillin }+ \\
\text { gentamicin ( } 2 \text { or } 3 \text { uptakes/day) } \\
\text { for } 4 \text { to } 6 \text { weeks } \\
\text { Regimen "B": } \\
\text { ampicillin + ceftriaxone for } 6 \\
\text { weeks }\end{array}$ & $\begin{array}{l}\text { Regimen "A": } \\
\text { amoxicillin ( } 4 \text { to } 6 \text { weeks) }+ \\
\text { gentamicin (single daily dose for } \\
2 \text { to } 6 \text { weeks) } \\
\text { Regimen "B": } \\
\text { ampicillin + ceftriaxone for } 6 \\
\text { weeks }\end{array}$ \\
\hline
\end{tabular}

* Including endocarditis of prosthetic valve implanted $>1$ year earlier.

** Rifampicin is only indicated in the presence of a prosthetic valve and, according to some experts, should be introduced later on (5 to 7 days after antibiotic therapy initiation). 